\title{
Mengawali Wirausaha dengan Outsourcing \& Freelancing
}

\author{
Agung Purnomo \\ Institut Teknologi Kreatif Bina Nusantara Malang \\ agung.purnomo@binus.ac.id
}

\section{Pengantar}

Seorang pengusaha bisnis pemula (business startup) tidak pernah ada cukup waktu untuk menyelesaikan semua tugas bisnis dalam sehari. Tapi itu tidak selalu berarti anda sebagai pengusaha bisnis pemula harus siap mempekerjakan karyawan tetap penuh waktu untuk bisnis anda. Karyawan penuh waktu menuntut ketersediaan beban gaji bulanan dan kantor. Padahal umumnya pengusaha bisnis pemula menghadapi tantangan keterbatasan sumberdaya keuangan. Untuk pekerjaan yang berada di antara batas-batas apa yang dapat anda lakukan secara realistis dan pekerjaan yang benar-benar anda harus lakukan dengan mempekerjakan karyawan, ada sejumlah besar tugas dan pekerjaan yang sebenarnya dapat anda lakukan dengan alih daya (outsourcing) dan pekerja lepas (freelance).

\section{Outsourcing}

Alih daya atau outsourcing adalah praktik yang menggunakan layanan pihak eksternal untuk mengurangi biaya dengan mengalihkan sebagian pekerjaan ke pemasok luar daripada menyelesaikannya secara internal. Outsourcing dikenal sebagai strategi penghematan biaya yang efektif bila digunakan dengan benar. Terkadang lebih terjangkau untuk membeli barang atau menggunakan jasa dari perusahaan lain, daripada menghasilkan barang atau menggunakan sumberdaya secara internal.

Bagi karyawan di Indonesia istilah outsourcing sering diasosiasikan dengan ketidakpastian dalam pekerjaan. Setelah kontrak kerja sebagai karyawan outsourcing selesai, status mereka sudah bukan pekerja lagi dan tak ada tanggung jawab bagi perusahaan untuk membayar uang pesangon dan asuransi kerja. Regulasi tentang outsourcing di Indonesia diatur melalui Undang-undang Nomor 13 Tahun 2003 tentang Ketenagakerjaan pada pasal 64,65, dan 66.

Outsourcing lebih menawarkan keuntungan bagi pengusaha khususnya diawal wirausaha. Wirausaha bisa menghemat sekitar 15\% karena pengurangan 
biaya yang dihasilkan dari outsourcing. Hasil penelitian Datamark, Inc. tahun 2014 mengklaim bahwa setiap kliennya dapat menghemat 31\% lebih dari satu tahun ketika mengalihkan satu aspek dari proses bisnisnya. Lebih dari tiga tahun, penghematan biaya naik menjadi 33\%. Survei global outsourcing Deloitte di tahun 2014 mewawancarai responden dari 22 sektor industri dan 30 negara. Deloitte menemukan $69 \%$ perusahaan yang disurvei lebih cenderung melakukan outsourcing karena teknologi komputasi awan (cloud computing). Sebanyak 66\% perusahaan ingin melakukan outsourcing proses bisnis tertentu sebagai layanan. Hingga 53\% responden survei mengalihkan fungsi IT mereka di tahun 2014, sementara 26\% perusahaan yang tidak melakukan outsourcing pada saat yang direncanakan akan melakukannya di masa depan.

\section{Freelancing}

Freelance atau pekerja lepas adalah jenis pekerja yang berdasarkan kontrak untuk berbagai perusahaan, bukan bekerja sebagai karyawan untuk satu perusahaan. Pekerja lepas sering dianggap wiraswasta, dan memiliki kebebasan untuk memilih dan memilih proyek dan perusahaan yang ingin mereka asosiasikan.

\section{Cara Outsourcing dan Freelancing}

Ada beberapa cara untuk melakukan outsourcing \& freelancing dengan berbagai tingkat anggaran dan keandalan, diantaranya melalui:

1. Agen atau perusahaan outsourcing atau pemborong atau penyedia tenaga kerja profesional

Perusahaan yang mendukung sesuai kebutuhkan anda dan meminta mereka melakukan pekerjaan untuk anda. Perusahaan tersebut akan mencarikan karyawan untuk perusahaan anda atau melayani kebutuhan salah satu proses produksi atau jasa yang anda butuhkan.

2. Website outsourcing dan freelancing

Contoh layanan outsourcing dan freelancing di Indonesia yang berbasis online, diantaranya: sribu.com, project.co.id, freelancer.co.id, sribulancer.com. Contoh layanan outsourcing dan freelancing tingkat internasional yang berbasis maya, diantaranya: freelancer.com, upwork.com, fiverr.com, guru.com, toptal.com, 99designs.com. Di web tersebut anda akan memposting kebutuhan anda dan meminta perusahaan atau freelancer individu untuk mengerjakan kebutuhan anda. Anda dapat memposting sebuah proyek dalam semalam dan menemukan orang yang tepat dengan tawaran pertama atau anda bisa menunggu sepanjang minggu dan masih merasa tidak ada yang cocok untuk pekerjaan itu. Ketika ada 
orang yang menawarkan diri untuk membantu proyek anda, anda dapat melihat portofolio dan kinerja orang tersebut. Sebagai pertimbangan apakah anda menerima atau menolak penawaran dia.

\section{Manfaat Outsourcing dan Freelancing bagi Pengusaha Pemula}

Berikut beberapa manfaat outsourcing dan freelancing bagi pengusaha pemula, diantaranya:

1. Bayar sesuai spesifikasi hasil kerja

Jika anda seorang pengusaha yang hanya memerlukan seseorang untuk membantu tugas khusus atau untuk proyek yang sangat spesifik, maka pekerjaan outsourcing memungkinkan anda menyelesaikan lebih banyak, sementara anda hanya membayar sejumlah sumber daya yang benar-benar anda butuhkan atau sesuai hasil kerja outsourcing-freelancing. Daripada membayar karyawan tetap hanya untuk mendesain logo atau website, lebih baik membayar freelance atau outsourcing.

2. Online dan dimana saja

Outsourcing bisa dilakukan melalui web atau online, tanpa perlu bertatap muka sehingga bisa dimana saja dan kapan saja. Tim outsourcing anda dapat berbasis di manapun di dunia dan selama anda dapat mengkomunikasikan pekerjaan dengan efisien, Anda dapat sering melakukan outsourcing pekerjaan pada atau bahkan di atas tarif lokal mereka sambil tetap menabung uang secara komparatif untuk merekrut di pasar Anda sendiri. Anda dapat memposting beberapa pekerjaan melalui situs outsourcing-freelancing dan membayar biaya untuk memiliki pilihan yang bekerja untuk mengembangkan beberapa ide jadi. Sehingga anda tahu persis apa yang anda dapatkan dan cukup membayar hasil terbaik dari pilihan Anda. Apapun bidang keahlian yang anda cari mungkin juga memiliki beberapa papan pekerjaan di mana anda dapat memposting proyek anda jika anda dapat menemukannya.

3. Tenaga ahli tanpa biaya kantor

Ini bukan hanya tentang peningkatan kapasitas. Anda juga bisa mempekerjakan orang-orang yang jauh lebih terampil daripada anda di area tertentu dan keindahan online outsourcing adalah mereka akan bekerja tanpa lelah dalam proyek Anda di lingkungan mereka sendiri. Sehingga anda hanya perlu mendanai karya itu sendiri. Bukan ruang kantor dan biaya tetap lainnya. 


\section{Jenis Pekerjaan untuk Outsourcing dan Freelancing}

Memilih jenis pekerjaan yang akan anda outsource akan bervariasi tergantung pada bisnis anda. Namun hal yang umum adalah logo, website, product knowledge, dan pemrograman sistem bisnis. Sementara anda tidak perlu melakukan pekerjaan itu sendiri, Anda tetap harus mengelola menemukan orang yang tepat dan memastikan anda telah memberikan detail yang cukup di setiap tahap. Oleh karena itu, yang terbaik adalah melakukan outsourcing proyek di mana anda bisa mendapatkan keuntungan dari seseorang yang lebih terampil daripada anda atau saat dibutuhkan waktu penyelesaian proyek akan jauh lebih tinggi daripada waktu yang diperlukan untuk mengelola proyek.

\section{Penutup}

Dengan demikian, memulai wirausaha dengan outsourcing dan freelancing bisa menjadi opsi strategi dan operasional bisnis yang menarik dan menguntungkan untuk diimplementasikan.

\section{References}

Anna Johansson. 2015. The 15 Best Freelance Websites to Find Jobs. https://www.entrepreneur.com/article/245953

Business Dictionary. 2017. Freelance.

http://www.businessdictionary.com/definition/freelance.html

Daniel McClure. 2017. Getting Started With Outsourcing.

https://themodernentrepreneur.com/start-outsourcing/

Investopedia. 2017. Outsourcing.

http://www.investopedia.com/terms/o/outsourcing.asp

Undang-undang Nomor 13 Tahun 2003 tentang Ketenagakerjaan.Gregory Ciotti. 2017. Best Web Analytics. http://www.sparringmind.com/best-webanalytics/ 